1951 to Dr. H. H. Blache, of Denmark, for his contributions to the advancement of mechanical engineering, and particularly for his pioneer work in the development of the large marine diesel engine. Dr. Blache was nominated by the Danish Society of Engineers. The Medal, which is in gold, was founded in 1936 to commemorate the bicentenary of the birth of James Watt, on January 19, 1736, and is the highest honour the Institution can bestow. It is awarded every two years for distinction in mechanical engineering in any direction-science, research, invention or production.

\section{Thomas Young Oration of the Physical Society}

DR. W. D. WRIGHT, of the Imperial College of Science and Technology, London, will deliver the Physical Society's Thomas Young Oration for $195 \mathrm{I}$. This Oration is a biennial event which is devoted alternately to physical and physiological optics. Dr. Wright's subject is "Modern Problems in Colorimetry", and the Lecture will be given in the Science Museum, Exhibition Road, London, S.W.7, on February 23 at 5.30 p.m. Apart from some work in the United States with Zworykin and others on television cameras, during which he designed a very successful type of Kerr cell, Dr. Wright's main research field over a period of twenty-four years has been the subject of vision-especially colour vision. For the study of normal and abnormal colour mixture data, he designed a new trichromatic colorimeter with spectral primaries, and the results obtained with this apparatus were employed (in association with data due to Guild) to define the standard colour-mixture data adopted by the International Illumination Commission. Besides a complete survey of abnormal colour vision, he has done work on the luminosity curve of the eye both for the foveal and extra-foveal areas (and also with very restricted fields) and on the sensitivity of the eye to differences in hue and differences in chromaticity. Dr. Wright's interest in colour has included the technical aspects of colour measurement, including the improvement of practical systems for use in industrial and commercial operations, and these aspects are discussed in his book "The Measurement of Colour" (1944). In more recent years his interests have included studies of the saccadic movements of the eyes during fixation, and also of the role of convergence in stereoscopic vision.

Geography in the Australian National University: Prof. O. H. K. Spate

DR. O. H. K. Spate, reader in geography in the London School of Economics and Political Science, has been appointed to the chair of geography in the Research School of Pacific Studies at the Australian National University, Canberra. Dr. Spate had a brilliant academic career at Cambridge. In 1937 he was awarded his doctorate for a thesis on "London 1801-51 : a Study in Urban Geography". This was followed by five years as lecturer in the University of Rangoon. The war years caused an interruption in his academic career, and he was attached to the Inter-Services Topographical Department, S.E.A.C. in charge of the Burma section. During this time, Dr. Spate gained first-hand knowledge of India, Pakistan, Burma and Ceylon. Since the War, Dr. Spate's main interests have been in the regional and political geography of monsoon Asia. In 1947 he was associated as a technical adviser with the Punjab Boundary Commission. In recognition of his work on India and Burma the Royal Geographical Society awarded Dr. Spate the Gill Memorial in 1947. The subjects of Dr. Spate's published papers include many geographical topies related to Burma, India and Pakistan. He is also co-editor of the "Changing Map of Asia : a Political Geography", which is to be published soon. Dr. Spate expects to arrive in Canberra in June.

\section{Exhibition of Recent French Scientific and Technical Publications}

AN exhibition of recent French publications in science and technology, under the auspices of the French Embassy, was opened by Mr. J. D. Newth, president of the Publishers' Association, in the Science Library, South Kensington, on January 12. In welcoming the exhibition, Dr. Sherwood Taylor, director of the Science Museum, referred to the achievements of French men of science from the thirteenth century onwards, leading through those of the galaxy of mathematical astronomers of the eighteenth century up to those of two outstanding men of recent times, Pasteur and Poincaré. He also pointed out the contributions made by Frenchmen to the literature of technology, mentioning particularly Diderot and D'Alembert, and Dumas. In replying, M. René Varin, cultural counsellor to the French Embassy, apologized for the smallness of the exhibition, mentioning the great losses in young scientific workers sustained by France during the War. He referred to the great respect with which France regards English experimental science, as evidenced by the fact that at the present time nearly one hundred French scientific workers are carrying out research in Great Britain. In opening the exhibition, Mr. Newth congratulated the French publishers on the fine quality of the works displayed. $\mathrm{He}$ referred to the constant struggle waged by the Publishers' Association in Great Britain to reduce the restrictions imposed by various countries on the import of books ; this, with the help of Unesco, has recently had some success. The exhibition will remain open until January 23, after which it will tour a number of university towns.

\section{British Insecticides and Fungicides}

The Association of British Insecticide Manufacturers has issued a useful "Directory, 1950 : British Insecticides and Fungicides" (pp. 124; obtainable free, from the Association, 166 Piccadilly, London, W.1, 1950), which is intended mainly for use by overseas firms and organizations, but will also be found useful in Great Britain. The Association works jointly with the Ministry of Agriculture in the latter's scheme for the approval of proprietary products for crop protection. Section 1 of the Directory gives full details of member firms. Section 2 is a reproduction of colour plates from Bulletin 137 of the Ministry of Agriculture and Fisheries, showing stages of fruit bud development. Section 3 is a directory of products and services. It is divided into several sub-sections, each with brief descriptive notes, and ranges from aerial application substances to aerosols, and from fumigants to weed-killers and treewound paints. Names of the firms which supply each substance are listed, and the Directory is extended to include auxiliary agents such as wetters, spreaders and stickers. The publication is com. mercial rather than technical; but many advisory officers and others will find it useful. The introduction and salient headings are in six languages. 